\title{
Psychological expertise in the imperative of education and social practice
}

\author{
A. Yablonsky ${ }^{1}$, N. Rohalska ${ }^{1}$, L. Yatsenko ${ }^{1}$, N. Melnik ${ }^{2}$ \\ ${ }^{1}$ Nikolaev National University named after V. Sukhomlinsky, Nikolaev, Ukraine \\ ${ }^{2}$ National Aviation University, Ukraine \\ Corresponding author. E-mail: andrey.yablonskiy61@gmail.com, loroknataliia@gmail.com
}

Paper received 07.02.21; Accepted for publication 22.02.21.

\section{https://doi.org/10.31174/SEND-PP2021-247IX98-16}

\begin{abstract}
The article refers to the application of new special psychological knowledge in education - Education Psychological Expertise, which has a leading role in assessing complex projects focused on a multidimensional strategy aimed at overcoming innovation risks in conditions of uncertainty. The comparative analysis of forensic psychological expertise and psychological expertise education. Shows the abilities of Education psychological expertise to determine the current state and prediction of educational systems.
\end{abstract}

Keywords: litigation psychological expertise, education, humanitarian expertise, expert activity, object and subject expertise.

Introduction. An important prerequisite for the successful development of a system of any level, including social, is a clear understanding of the guidelines of the movement on the basis of consistent and balanced activities, a necessary and important component of which is expert activity. Modern post-industrial society is characterized by an increase in the priority of providing services over production, the organization of the education system, aimed ultimately at improving the quality of life of every person. This necessitates a comprehensive design of a system of measures aimed at the successful assimilation of humanitarian values, the development of humanitarian culture and strategy for the implementation of the principle of humanitarianism in educational practice.

Analysis of recent research. The specifics and features of humanitarian expertise in education are studied in the works of S. Bratchenko, D. Ivanov, R. Mkrtichyan, S. Deryabo, A. Tubelsky, etc.. Structural and semantic principles of expert research of psychological and pedagogical reality, principles, methodology and techniques psychological expertise of education is developed by $\mathrm{M}$. Alekseev, I. Baeva, S. Deryabo, D. Ivanov, O. Laktionova, V. Levy, G. Mkrtchyan, V. Panov, G. Prozumentova, A. Tubelsky, O. Furman, Yu. Schwalb and others. Most of these authors focus on the study of mainly applied aspects of expert activity in education, bypassing its theoretical foundations. Therefore, we have a variety of opinions and views on the formulation of the conceptual basis of humanitarian expertise of education.

The purpose of the article is to reveal the essence of psychological expertise of education based on its comparison with forensic psychological expertise, as well as to study its potential to determine the current state and forecast the development of educational systems to obtain an objective assessment of development prospects in uncertainty.

Materials and methods. Theoretical research methods are used in the work: logical-psychological and comparative analysis and systematization, generalization of scientific literature to determine the state of the problem, as well as theoretical modeling and scientific interpretation to determine the theoretical foundations of expertise as a psychological phenomenon; methods of interpretation (paradigmatic, categorical analysis) for a holistic presentation of the essence of psychological expertise of the content of general secondary education as a system of psychodiagnostic procedures of broad social practice. The basic position for the study is a systematic approach as an interdisciplinary methodological direction, adequate in the study of educational practice, as objectively there is a need to comprehensively consider all changes in the components of the modernizing education system and determine the end result of these changes as a specific educational product, or whether this product will be created at all.

Results and discussion. Radical changes in society at the turn of the XX and XXI centuries have led to the actualization of the idea of humanitarian expertise, its theoretical understanding and practical implementation as a phenomenon of social practice. The available approaches to clarifying the place of expertise in the system of psychological and human sciences are characterized by a variety of opinions. Some researchers see the expertise as an independent psychological science, others - a branch of practical psychology, others - consider it part of the future science - humanities expertise. The problem is that the expertise cannot be equated with something definite, homogeneous, clearly defined. Expertise in today's conditions is "a significant and diverse world of expertises: from situational tasting to the most complex research procedures, from various ratings on unclear criteria to clearly regulated by law forensic psychological expertise" [3, p.31]. The latter is the most developed in both theoretical and practical sense among all available psychological expertises. Today, most researchers of the theory of forensic science consider the object of expertise expert activity, some theoretical constructions in this field of scientific knowledge, methods of theory development and implementation of expert research, processes and relations, ie a comprehensive scientific reflection of forensic science as a whole. The object of expert research is an integral and defining feature of the species affiliation of expert research. Such definitions with some textual difference are given by M. Selivanov, N. Orlov, D. Mirsky. The authors of the collective monograph on forensic expertise believe that its object is a complex system with the following elements: material media of facts; source of information about the fact; mechanisms of information transmission from source to medium, ie reflecting and displaying components, as well as the mechanism of their interaction [1, p. 89].

It should be emphasized that the concept of the object 
is considered from the point of view of science and from the standpoint of practice. For science, an object is a type of object, class, or category of objects that has common qualities. From a practical point of view, an object is a specific object that is provided to an expert for research: physical evidence, including objects, mechanisms, aggregates, substances, materials, documents. Also, the objects of expertise, in addition to objects are events, facts, phenomena and other intangible objects, the need to study which in the process of investigation requires special knowledge and expert research [5].

Scientists also have different views on the classification of types of objects, which are classified on the following grounds:

- general (material media of facts of interest to the investigation and the court);

- generic (subject) (a set of material media, united by common qualities);

- special (material media of a certain nature);

- specific and direct.

The object of forensic expertise, therefore, is a specific individual subject provided for expertise in a particular case $[5, \mathrm{p}, 18]$.

The subject of forensic psychological expertise, according to many researchers in the field of legal psychology, are the facts, circumstances that are investigated by expertise and established in the investigation and consideration of a criminal or civil case on the basis of special knowledge.

According to N. Klimenko, the content of the subject of forensic expertise can also be considered from two positions - scientific and practical. From the point of view of the scientific field of knowledge, the subject of the science of forensic science is the patterns of formation of the qualities of objects and their changes in connection with the commission of a crime. From the point of view of practical activity, the subject of forensic expertise is factual data (circumstances of the case), which are established on the basis of special knowledge and research of materials of criminal, civil or economic case [5].

With regard to a particular expertise, its subject is an expert task that should be solved by the expert in the course and according to the results of the study on the basis of the appropriate amount of special knowledge using the tools and methods at his disposal. Thus, the correct definition of the subject of forensic psychological expertise plays a significant role in theoretical, practical, procedural and organizational and methodological aspects. After all, the subject of expertise is an essential feature of each kind and type of expertise, because it determines the nature and sources of special knowledge that the expert needs to obtain expert information and assess and conclude.

Unfortunately, humanitarian-psychological expertise, which, in contrast to forensic, has a broader context, in today's conditions only reaches the level of proper understanding. In this aspect, we should refer to the foreign experience of Western countries, where scientific expertise in the field of education has become widespread, which is carried out in the form of "pedagogical audit", "psychological and pedagogical expertise", "comprehensive humanitarian expertise", etc. [8].

Among the many areas of scientific expertise of educa- tion are the following:

1. Expertise of educational projects carried out under the auspices of UNESCO, UNICEF and other international organizations.

2. Expertise of regional (European, Asian, etc.) and national educational projects.

3. Expertise of development trends or changes in the content of education.

4. Expertise of educational reforms at different levels of educational systems.

5. Expertise of individual programs aimed at solving specific educational problems.

6. Expertise of educational institutions and centers.

7. Expertise of textbooks, manuals, teaching materials, etc.

8. Expertise of knowledge assessment systems.

9. Expertise of mental and physical health of students.

10. Expertise of training (including experts) for the educational sphere.

11. Expertise of educational resources, including Internet resources and textbooks.

The selected areas of scientific psychological expertise of education do not cover the full range of problems of expertise in the field of education. Thus, Western countries, according to M.-L. However, there is already an extensive hierarchical system of "expert support of projects" and therefore virtually no educational innovation bypasses expert evaluation at various stages of its implementation and implementation. In Western countries, there is a professional environment of expert communities with centers for training experts, with discussions of urgent and scientific issues of expertise in many periodicals [8]. We agree with the author that such processes have long been relevant in Ukraine and need an urgent solution.

In our opinion, the relevance of psychological expertise of education is associated with continuous change, the development of society in the XXI century. The nature of this process of change, mechanisms and means, the ability to manage them are still poorly understood. Global innovation processes in society are accompanied by the accelerated development of all aspects of social life, which deepens the contradiction between the pace of social and individual socio-cultural development. Innovative education, which is constantly evolving in today's conditions, requires self-knowledge and psychological and pedagogical understanding.

It should be emphasized that education is a sociocultural phenomenon and performs a socio-cultural function, which is why it is an important way to socialize the individual, the space of his communication and human involvement in universal and national values. Education, like socialization, is always about personality. However, there are certain features that I. Bech emphasizes: "Although education recognizes the necessary prerequisite for its existence external moments that have a certain influence on it, this process of mastering the world takes place within the individual, in the space of the subject's worldview. At the same time, education is an internal process that develops under the influence of internal motivations and interests of the individual " $[2$, p. 6].

Thus, the external elements of social reality can only prepare the educational process, give it innovation, while 
the development of personality always takes place in the plane of the subject, due to his own activity. In view of the above, it is necessary to identify opportunities and ways to coordinate innovation processes with all processes of social and personal life, promote mutual development and positive self-realization of the creative potential of society and each individual, in particular, harmonizing and matching them with the natural conditions of their activities.

At the present stage, education solves not only the development of cognitive abilities of the individual. Its conceptual basis is the involvement of the younger generation in modeling social dialogue, the development of the need to construct their social experience, pass it on to others, as well as actively perceive and transform the experience of others in their own lives. Eventually, the individual becomes a whole person in the full sense of the word. "From a man of the XXI century. special mobility and the ability to adapt to drastic changes in living conditions, changing professions, cultural environment and communication conditions will be required. An indicator of global human mobility (ethnicity, nation, state) will be education and the ability to strain, move, mobilize and learn all life to keep up with the times "- emphasizes T. Usatenko [7, p. 120]. Therefore, the purpose of humanitarian and psychological expertise in education as a special method of diagnostic study of educational processes and phenomena is to serve as a means of such selfknowledge and reflection on its development.

Psychological expertise of education, thus, is a special form of scientific and practical knowledge of objective reality, which is based on certain methodological principles, patterns, interdisciplinary links and aims to determine the current state and forecast the development of educational systems to obtain an objective assessment of prospects development in conditions of uncertainty. Psychological expertise is based on the fact that the development of innovation in society should be balanced by the development of anthropological, social, professional, ideological, moral, spiritual, cultural, general humanitarian sphere and indicates how it should happen in each case of innovative impact on society. . Given the discipline and interdisciplinarity of knowledge as the basis for expertise, the latter is a complex multidisciplinary or multidisciplinary, as an innovative product (educational process) is developed at the intersection of different scientific disciplines and requires competent assessment by experts. Here it is appropriate to cite the absolutely rational opinion of M.-L.A. Chepa: "Expert activity cannot be carried out by amateurs. Experts need to be trained, to create an infrastructure for professional communication, to process expertise procedures to protect expert opinions from bias, political bias, bias"[8]. It should also be emphasized that the demand for high-quality expert opinions is growing in all spheres of social life. Clients of such expertises do not have objective criteria for the selection of experts (except for persons with academic titles and degrees) and, most importantly, do not have criteria for evaluating the provided expert opinions. Experts themselves, in undertaking expert tasks, also do not rely on a clearly defined methodology, mixing expertise with consulting, diagnosis, assessment, monitoring, etc.

Like every kind and type of expertise, psychological expertise of education has its own specifics, subjective and personal grounds - it is its strength and its weakness. The strength of the expertise, according to S. Bratchenko, is that experience, intuition, creative search of the expert allow to catch the elusive, in contrast to strictly objective procedures, to penetrate into the hidden essence of the phenomena. At the same time, the personal nature of the expert's knowledge adds responsibility for the opinions and decisions expressed by him. The weakness is manifested in the fact that each subjective opinion necessarily bears the imprint of its author, and therefore is specific, and usually corresponds to one point of view. S. Bratchenko proposes to compensate for this inevitable dependence of the expertise by involving several experts in solving the expert submission [3].

The introduction of scientific support for the development of Ukrainian education by means of scientific expertise requires a theoretical understanding of the essence of psychological expertise of education, and therefore, the question arises about its object and subject. Given that the national education system is a key element in the development of society and the state, the actual field of expertise should be all the latest educational phenomena and processes. It should be emphasized that in foreign practice in recent decades there is a growing understanding that no serious educational project or program can do without expert research. In this case, they are considered incomplete because their effectiveness has not been evaluated. This is the point of view of A. Tubelsky and R. Mkrtychyan, whose idea of the object of expertise is associated with its interpretation as a means of studying educational phenomena and processes [6].

At the same time, there is a widespread view among scholars that the object of expertise should be the entire pedagogical field as a whole. Among the supporters of such an understanding of the object of expertise can be called S. Bratchenko, who tried to systematize its objects. According to the author, it is expedient to use the following objects for humanitarian expertise: students, teachers, the educational process, the way of life of the educational institution, the educational environment, the social environment. The purpose of expertise in education can be: assessment of compliance of educational programs with current psychological and didactic requirements; evaluation of the effectiveness of author's and experimental programs, educational technologies and systems; assessment of the readiness of the personnel potential of the educational institution to work in certain conditions and with appropriate technologies; assessment of the effectiveness of administrative and managerial activities in accordance with regulatory state documents; assessment of the level of development of abilities of subjects of study [3].

A slightly different vision of the subject of expertise of the educational process was formulated by D. Ivanov. The author believes that the subject of the expertise is not to establish the conformity of its results to certain norms, but the process of activity, its changes both in the pedagogical field and in the field of management. According to the author, during the expertise it is necessary to determine the existence of the process of change (whether there is a change in the content of education, whether the search for new ways to organize the educational process and interac- 
tion with learners, etc.). The main purpose of the expertise in education is to provide assistance, support to the staff of educational institutions to implement certain changes and manage them both at the design stage and at the stage of its implementation [4, p. 245-246].

Thus, the considered approaches to the interpretation of the concept of expertise, its content, object and subject of expert activity allow to characterize the expertise of education as a closed expert action, which corresponds to the modern practice of its application in education. At the same time, scholars often criticize the closed expertise and the existing forms of its organization. Emphasis is placed on the need not to improve the procedures of expert work, its professionalization, limiting the scope and finally - the humanization of its content and procedures, which will transform the expertise into an open expert action and improve its results. The latter will not only record positive or negative changes, but also affect the effective change of educational practice, the introduction of new management mechanisms of educational management.

Conclusion. The concept of "psychological expertise" is defined as an important thinking tool of modern psychological discourse, aimed at forming an external, independent, methodologically balanced expert opinion on the results and delayed effects of internal and external factors on the formation and development of personality. Psychological expertise of education has a leading role in the assessment of complex projects focused on a multidimensional strategy aimed at overcoming innovation risks in conditions of uncertainty.

Theoretical and experimental studies of psychological expertise of education create prerequisites for its holistic understanding as one of the priority areas of psychological theory and practice, which in today's conditions requires theoretical and methodological understanding, and expanding its impact on the education system, creating an innovative sector based on human resources, human capital of the educational system itself. The above defines such functions of psychological expertise of education as: explanatory, protective, developmental, evaluative, legalization function, consultative, monitoring, reflective and prognostic, which is the prospect of further scientific research.

\section{ЛІТЕРАТУРА}

1. Аверьянова Т.В.Судебная експертиза. Курс общей теории. М.: Норма, 2006. 477 c.

2. Бех І.Д. Виховання особистості: У 2 кн. Кн. 2: Особистісно орієнтований підхід: науково-практичні засади. К.: „Либідь”, 2003. 344 с.

3. Братченко С. Л. Введение в гуманитарную экспертизу образования (психологические аспекты). М.: Наука, 1999 $210 \mathrm{c}$.

4. Иванов Д.А. Экспертиза в образовании: учеб.пособ.для студентов высших учеб заведений. М.: Изд. Цетр “Академия", 2008. $336 \mathrm{c}$.

5. Клименко Н.І. Судова експертологія: Курс лекцій: Навч.

посчб. для студ. юрид. спец. вищ. навч. закл. К.: Видавничий дім “Ін Юре”, 2007. 528 с.

6. Мкртичян Р.А. Психолого-педагогическая экспертиза инноваций в образовании. Весник ННГУ, 2005. Випуск 1 (6) . C.152-155

7. Усатенко Т.П. Українська національна школа: минуле i майбутнє. Українознавчий вимір. К.: Наукова думка, 2003. $285 \mathrm{c}$

8. Чепа М.-Л.А. Психологічна експертиза освіти. Збірник наукових праиь інституту психологї̈ ім. Г.С.Костюка НАПН Украӥни. Т.ХІІ. Ч 5. 2011. С. 337-341.

\section{REFERENCES}

1. Aver`yanova T.V.Sudebnaya eksperty`za. Kurs obshhej teory`y'[ Forensic expertise. General theory course]. M.: Norma, 2006. $477 \mathrm{~s}$.

2. Bex I.D. Vy`xovannya osoby`stosti [Education of personality]: U 2 kn. Kn. 2: Osoby`stisno oriyentovany`j pidxid: naukovo-prakty`chni zasady`. K.: „Ly`bid”, 2003. $344 \mathrm{~s}$.

3. Bratchenko S.L. Vvedeny`e v gumany`tarnuyu эksperty`zu obrazovany`ya (psy`xology`chesky`e aspektы) [Introduction to the humanitarian expertise of education (psychological aspects)]. M.: Nauka, 1999. $210 \mathrm{~s}$.

4. Y`vanov D.A. Эksperty`za v obrazovany`y`: ucheb.posob.dlya studentov vыsshy`x ucheb zavedeny`j [Expertise in Education: Textbook for Students of Higher Education]. M.: Y`zd. Cetr “Akademy”ya”, 2008. . 336 s.

5. Kly`menko N.I. Sudova ekspertologiya [Forensic expertise]: Kurs lekcij: Navch. poschb. dlya stud. yury`d. specz. vy`shh. navch. zakl..K.: Vy`davny`chy`j dim "In Yure”, 2007. . 528 s.

6. Mkrty`chyan R.A. Psy`xologo-pedagogy`cheskaya эksperty`za y`nnovacy`j $\mathrm{v}$ obrazovany`y'[Psychological and pedagogical expertise of innovations in education] Vesny`k NNGU, 2005. Vy`pusk 1 (6) . S.152-155

7. Usatenko T.P. Ukrayins`ka nacional`na shkola: my`nule i majbutnye. Ukrayinoznavchy`j vy`mir [Ukrainian national school: past and future. Ukrainian studies dimension]. K.: Naukova dumka, 2003. $285 \mathrm{~s}$.

8. Chepa M.-L.A. Psy`xologichna eksperty`za osvity` [Psychological expertise of education]. Zbirny`k naukovy`x pracz insty`tutu psy`xologiyi im. G.S.Kostyuka NAPN Ukrayiny`. T.XII. Ch 5. 2011. S. 337-341. 